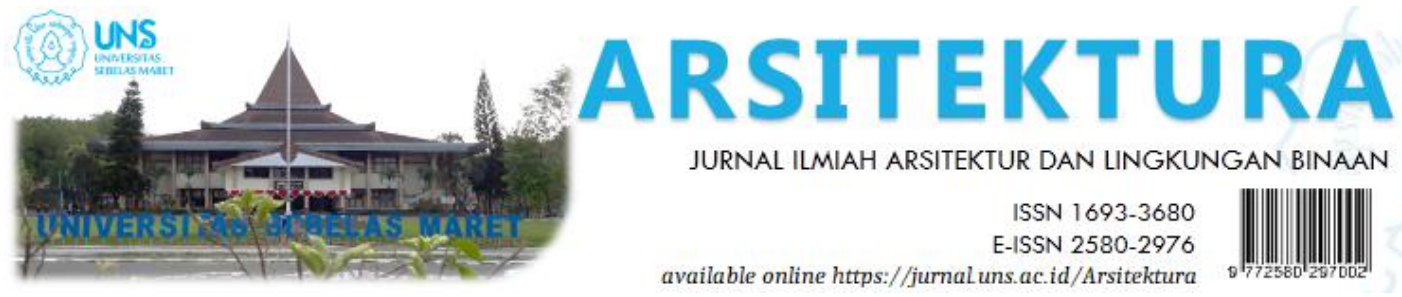

Volume 19 Issue 2 October 2021, pages: 275-288

\title{
Identifikasi Tingkat Kekumuhan Pada Kabupaten Langkat Dengan Metode AHP (Analytical Hierarcy Process)
}

\section{Identification of Slum Level in Langkat Regency by AHP (Analytical Hierarcy Process) Method}

\author{
Yunita Syafitri Rambe \\ Program Studi Arsitektur, Fakultas Teknik, Universitas Medan Area Department, Faculty University \\ Email: yunirambe@staff.uma.ac.id
}

DOI: https://doi.org/10.20961/arst.v19i2.51478

Received: May 24,2021 Revised: October 25,2021 Accepted: October 26,2021 Available online: October 30,2021

\begin{abstract}
Problems that occur in an urban level of uneven service facilities and infrastructure especially in the urban suburbs. This is also the case in Langkat Regency. The existence of these settlements is classified into squatters or slums that grow unplanned on unlicensed state land. The purpose of the research is to identify the slums, using the AHP method, starting from the collection of primary and secondary data, field observations, interviews and documentation, which are then assessed against the criteria that have been set. The final result of the weighting resulted in the classification of the level of slums in the village. It is hoped that the results of this study can be useful for other research.
\end{abstract}

Keywords: Slum Area; Langkat Regency; AHP

\section{PENDAHULUAN}

Timbulnya arus urbanisasi yang meningkat setiap tahunnya menimbulkan banyak masalah seperti susahnya mendapatkan pekerjaan, tidak meratanya pertumbuhan perkotaan sehingga dalam beberapa titik perkotaan akan membentuk ruang-ruang permukiman kumuh. Pada Kabupaten Langkat sebagai wilayah penelitian dilihat dari RPJMD, isu yang dirasakan pada beberapa tahun terakhir yaitu adanya permasalahan permukiman kumuh. Hal ini menjadi salah satu isu utama pembangunan yang cukup menjadi polemic. Dikatakan demikian karena peanganan permukiman kumuh sudah dijalankan dari beberapa tahun lalu, tetapi perkembangan pembangunan terhadap permukiman kumuh tidak terlihat perbandingan perrkembangan kawasan kumuh dan munculnya kawasan-kawasan kumuh bar uterus terjadi setiap tahunnya. Ini menjadi sumber masalah dalam suatu kota.(Stabat, n.d.) Sehingga diperlukannya suatu strategi agar keberlanjutan sebuah kota menjadi lebih baik lagi. Tujuan dari penelitian ini untuk dapat mengidentifikasi titik-titik kumuh pada kabupaten Langkat yang selanjutnya dilakukan analisis dan penilaian tingkat kekumuhan berdasarkan kriteria yang ada. Hasil dari penelitian ini diharapkan dapat menjadi dasar dan prioritas penanganan Kawasan.

Dilain sisi di bidang tatanan sosial budaya kemasyarakatan, komunitas yang bermukim di lingkungan permukiman kumuh secara 
ekonomi pada umumnya termasuk golongan masyarakat berpenghasilan rendah, yang seringkali menjadi alasan penyebab terjadinya degradasi kedisiplinan dan ketidaktertiban dalam berbagai tatanan sosial masyarakat. Permasalahan permukiman kumuh pada Kabupaten Langkat semakin berkembang ke setiap daerah sehingga perkembangan ruang kota tidak sesuai dengan fungsi aslinya, yang mengakibatkan munculnya kantung-kantung permukiman pada lahan-lahan yang tidak sesuai dengan peruntukkannya (squatters), tingkat kepadatan bangunan yang tinggi, kualitas bangunan dan kualitas sarana dan prasarana yang tidak memenuhi syarat standar pelayanan minimal (SPM) perkotaan pada beberapa kawasan permukiman di Kabupaten Langkat.

Berdasarkan UU Nomor 1 Tahun 2011 tentang Perumahan dan Kawasan Permukiman, bahwasannya Permukiman kumuh adalah suatu kawasan dengan bentuk hunian yang tidak berstruktur, tidak berpola (misalnya letak rumah dan jalannya tidak beraturan, tidak tersedianya fasilitas umum, prasarana dan sarana air bersih, MCK) bentuk fisiknya yang tidak layak misalnya secara reguler tiap tahun kebanjiran. (Zulkarnaini et al., 2019). UN Habitat dalam Slum Almanac (2015) mendefinisikan permukiman kumuh sebagai permukiman informal dengan ciri perumahan semi permanen, padat, tidak memiliki akses air, sanitasi dan keamanan yang baik. Hal ini menyebabkan penduduk yang lahir di daerah kumuh mempunyai standar hidup tidak membaik dari waktu ke waktu. Permukiman kumuh di negara berkembang saat ini juga dianggap sebagai bentuk jebakan kemiskinan bagi mayoritas penduduk mereka (Marx et al., 2013)

Menurut Khomaruddin (1997) dalam tesis lingkungan permukiman kumuh didefenisikan sebagai (1) lingkungan yang berpenghasilan padat dengan 500 orang per hektar, Kondisi social ekonomi masyarakat rendah, jumlah rumahnya sangat padat dan ukuran dibawah standar, sarana dan prasarana tidak memenuhi standar Kesehatan, tanah yang dipakai untuk membangun hunian bukanlah tanah pribadi melainkan tanah milik pemerintah ataupun orang lain. (Kasus et al., 2006)
Menurut David Drakakis Smith dalam May I (2014) slum area atau area kumuh adalah lingkungan permukiman yang abash, legal dan permanen tetapi kondisi fisik terhadap lingkungan semakin memburuk karena kurang terpelihara, umur bangunan yang semakin lemah, ketidakperduliaan masyarakat, atau terbagi-bagi menjadi unit perkarangan rumah kamar yang semakin mengecil. (Istikasari \& Khadiyanto, 2014)

Menurut Basri (2010), tidak semua pada Kawasan kumuh dihuni oleh masyarakat miskin. Dalam hal ini, yang mencirikan Kawasan dikatakan kumuh dapat dibagi menjadi 2, yaitu:

1. Kawasan tersebut tidak atau kurang terlayani dengan infrastruktur pendukung kawasan seperti jaringan jalan, drainase, saluran limbah dan lain-lain, sehingga kawasan tersebut cenderung mengalami degradasi; dan

2. Hunian di kawasan tersebut secara kasat mata terlihat tidak layak huni yang ditandai dengan kurangnya ventilasi maupun pencahayaan, disamping mutu material bangunannya yang tidak layak dijadikan sebagai bahan bangunan untuk sebuah hunian.

Untuk mengetahui kantung-kantung permukiman kumuh, terlebih dahulu mengetahui komponen baik terhadap bangunan dan sarana prasarana terhadap lingkungannya. Terdapat 7 komponen Kawasan permukiman kumuh, yaitu (Ilmy \& Budisusanto, 2017)

Tabel 1. Komponen Permukiman Kumuh

\begin{tabular}{|c|c|c|}
\hline NO & PARAMETER & SUB KRITERIA \\
\hline \multirow[t]{3}{*}{1} & $\begin{array}{l}\text { Kondisi Bangunan } \\
\text { Gedung }\end{array}$ & $\begin{array}{l}\text { Ketidakteraturan } \\
\text { Bangunan }\end{array}$ \\
\hline & & $\begin{array}{l}\text { Tingkat } \\
\text { Bangunan }\end{array}$ \\
\hline & & $\begin{array}{ll}\text { Ketidaksesuaian } & \text { dengan } \\
\text { Peryaratan } & \text { Teknis } \\
\text { Bangunan } & \end{array}$ \\
\hline \multirow[t]{2}{*}{2} & $\begin{array}{ll}\text { Kondisi } & \text { Jalan } \\
\text { Lingkungan } & \end{array}$ & $\begin{array}{l}\text { Cakupan Pelayanan Jalan } \\
\text { Lingkungan }\end{array}$ \\
\hline & & $\begin{array}{l}\text { Kualitas Permukaan } \\
\text { Jalan Lingkungan }\end{array}$ \\
\hline 3 & & $\begin{array}{l}\text { Ketidaktersediaan Akses } \\
\text { Aman Air Minum }\end{array}$ \\
\hline
\end{tabular}




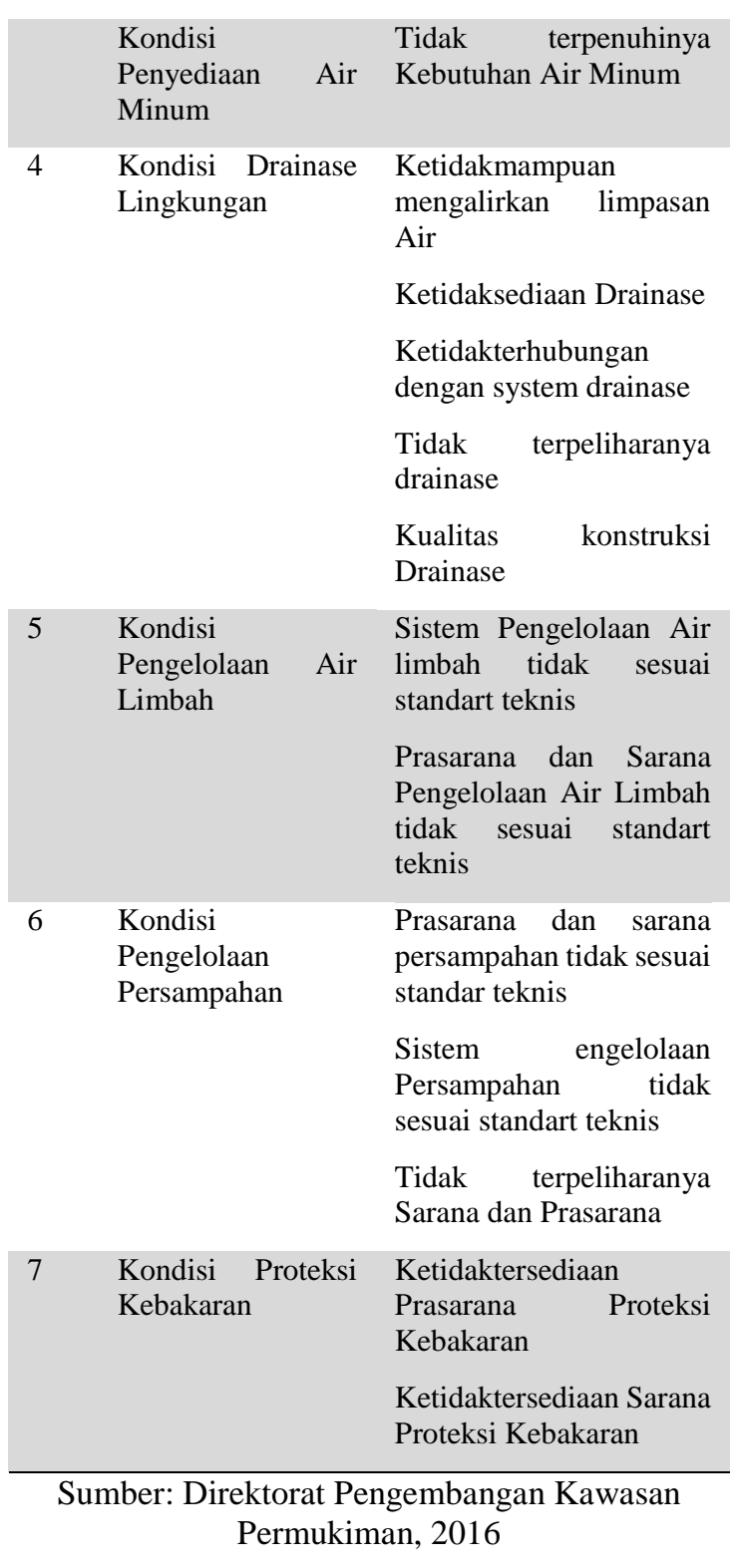

Masalah yang terkait dengan kualitas lingkungan hidup masyarakat kota, meliputi aspek fisik seperti kualitas udara, air, tanah; kondisi lingkungan perumahannya seperti kekumuhan, kepadatan yang tinggi, lokasi yang tidak memadai serta kualitas dan keselamatan bangunannya; ketersediaan sarana dan prasarana serta pelayanan kota lainnya; aspek sosial budaya dan ekonomi seperti kesenjangan dan ketimpangan kondisi antar golongan atau antar warga, tidak tersedianya wahana atau tempat untuk menyalurkan kebutuhan-kebutuhan sosial budaya, seperti untuk berinteraksi dan menyampaikan aspirasi-aspirasi sosial budayanya; serta jaminan perlindungan hukum dan keamanan dalam melaksanakan kehidupannya. Kohesi sosial dan kesetaraan merupakan faktor penting dalam kualitas hidup di perkotaan.(Ahaliki, 2020).

\section{METODE}

Pada penelitian ini, metodologi yang digunakan adalah jenis metode deskriptif dengan cara melakukan survey lapangan baik dengan pengambilan data sekunder dan data primer dari pihak terkait dan masyarakat. Selain itu untuk menambah keakuratan data yang diperoleh maka dilakukan wawacara, observasi, survey lokasi dan studi dokumentasi sebagai data awal dasar pengelompokkan identifikasi berdasarkan tinjauan teori dan peraturan perundangan.

Lokasi penelitian berada pada Kabupaten Langkat yang terdiri dari 21 Kecamatan dan 91 Kelurahan. Di setiap Kecamatan tersebar Kawasan kumuh dengan persentase kekumuhan berbeda-beda. Dari hasil analisis terhadap sarana dan prasarana terdapat 6 Kecamatan. Sehingga penelitian yang akan dilakukan terhadap 6 Kecamaatan yang berada di Kabupaten Langkat.

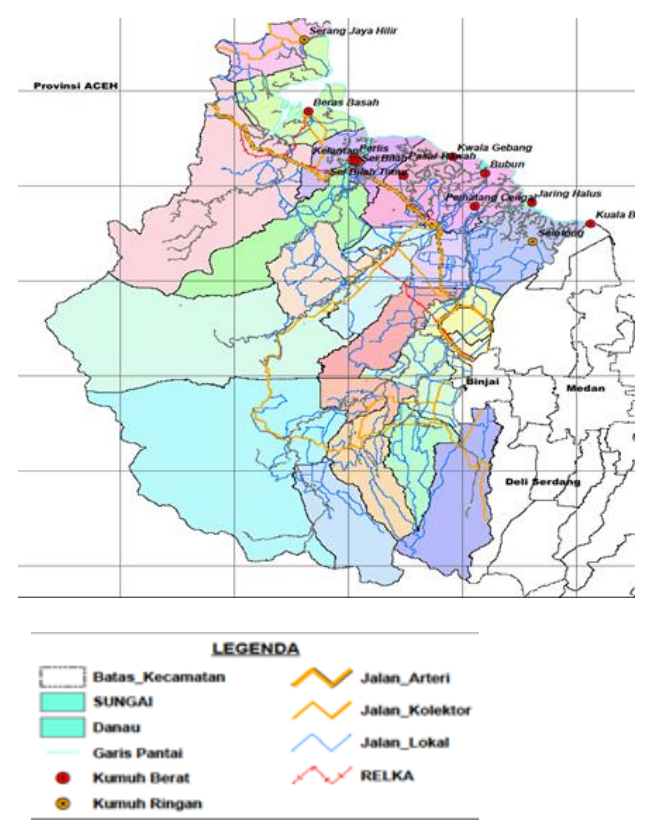

Gambar 1. Sebaran Kumuh Kabupaten Langkat Sumber: Kotaku, Kab. Langkat

Sistem teknik pengambilan keputusan dalam penelitian menggunakan metode analisis hierarki proses (AHP) yang merupakan metode yang tepat digunakan karena pada AHP menggunakan multicriteria yang dibandingkan 
dengan alternatif, sehingga mengurangi kesubjektifan dalam penentuan bobot kriteria. (Sastanti \& Fibriani, 2019)

Pemilihan metode ini juga dilakukan karena metode ini mempunyai struktur yang berhirarki untuk menjaga konsekuensi dari kriteria yang di pilih sampai kepada kriteria yang paling dalam, analisis ini juga salah satu sistem teknik pengambilan keputusan yang dapat dipahami, tidak kaku mudah disesuaikan untuk berbagai masalah. Dalam metode AHP pada penelitian ini, Langkah-langkah yang dilakukan adalah menentukan tujuan utama, dilanjutkan dengan kriteria atau faktor, sub kriteria atau sub faktor dan kemungkinan adanya alternatif-alternatif pada tingkatan. (Komunikasi et al., 2019)

Penilaian perbandingan berpasangan (pair-wise comparison) berdasarkan skala penilaian satu sampai dengan lima disertai adanya nilai tengah diantara nilai ganjil dengan menghasilkan nilai bobot faktor (weight Factor) dan nilai faktor evaluasi (evaluation factor), dimana nilai bobot alternatif yang tertinggi (weight score) maka nilai bobot tersebut merupakan prioritas (Khoirunnisa dkk, 2013).

Pada penelitian ini, tahapan metode AHP yang dilakukan dengan melakukan survey lapangan dan survey literatur yang berasal dari jurnal dan buku kajian terhadap Kawasan kumuh. Proses yang dilakukan dalam penelitian dengan menggunakan wawancara pada tiap Kabupaten dengan jumlah responden $70 \%$ dari jumlah KK yang berada di Kecamatan dengan kategori rumah kumuh. terhadap narasumber dalam hal ini Pihak Bappeda kabupaten Langkat yang memberikan arahan terhadap kabupaten nilai kekumuhan tertinggi. Arahan ini menjadi dasar dalam penelitian untuk dilakukannya survey lapangan dengan melakukan pengukuran secara satelit dan wawancara terhadap masyarakat setempat.

Data yang diperoleh akan dilakukannya perhitungan dengan metode AHP dengan perbandingan terhadap teori permukiman kumuh dan UU No 1 tahun 2011 dengan melihat kriteria penilaiaan terhadap 7 unsur yaitu Kondisi Bangunan Gedung, Kondisi Jalan Lingkungan, Kondisi Penyediaan Air Minum, Kondisi Drainase Lingkungan,
Kondisi Pengolahan Air Limbah, Kondisi Pengelolaan Sampah, dan Kondisi Proeksi Kebakaran.

Dengan hasil pengamatan lapangan, wawancara dan studi yang dilakukan terhadap buku dan dinas terkait, maka indicator Kawasan kumuh akan di lakukan penilaian dengan metode AHP melalui nilai scooring yang ada dengan membagi penilaian kualitas dari baik sampai buruk dengan persentase $0-100 \%$ dengan nilai 0 sampai 5. Lalu akan diakumulasi dengan menggunakan perhitungan yang sudah dibuat. Sehingga akan muncul total nilai kekumuhan yang diklasifikasikan dari kumuh ringan, berat dan sedang. Hasil dari analisis diperoleh perhitungan dari subkriteria setiap indicator melalui penilaian yaitu:

\begin{tabular}{|c|c|}
\hline $5 \%)$ & lai 0 \\
\hline Kualitas Cukup (26\%-50\%) & Nilai 1 \\
\hline Kualitas Kurang Baik (51\%-75\%) & Nilai 3 \\
\hline Kualitas Buruk (76\%-100\%) & ilai 5 \\
\hline $\begin{array}{l}\text { Setelah mendapatkan nila } \\
\text { rategori pada setiap Kawasan kı } \\
\text { Kecamatan, maka akan dilakukan p } \\
\text { lari setiap nilai untuk mendapatkan } \\
\text { lengan kategori }\end{array}$ & $\begin{array}{l}\text { terh } \\
\text { muh } \\
\text { njuml } \\
\text { nilai }\end{array}$ \\
\hline
\end{tabular}

71-95 : Kumuh Berat

45-70 : Kumuh Sedang

19-44 : Kumuh Ringan

Penentuan penangananan juga dengan melihat status legalitas lahan yang digunakan sebagai variabel pokok dalam perencanaan pola penanganan kawasan kumuh dan tipologi kawasan kumuh. (Crysta \& Budisusanto, 2018).

\section{HASIL DAN PEMBAHASAN}

Analisis dan temuan Tingkat kekumuhan suatu lingkungan permukiman dapat diukur dengan melihat pada indikatorindikator yang ada dan signifikan terhadap terjadinya kondisi kumuh pada suatu lokasi. Penilaian lokasi berdasarkan kriteria, indikator dan parameter kekumuhan merupakan tahapan untuk menilai lokasi permukiman kumuh sesuai dengan Peraturan Perumahan Rakyat Nomor 2 tahun 2016 tentang Peningkatan Kualitas Terhadap Perumahan Kumuh dan Permukiman 
Kumuh, di dalam mendapatkan klasifikasi tingkat kekumuhan dan daftar urutan (rangking) permukiman kumuh (PUPR, 2016).

Dari kawasan-kawasan yang memiliki indikasi tersebut kemudian dinilai berdasarkan kriteria dan indikator penentuan urutan kawasan prioritas. Adapun penilaian Kawasan perkumuhan, dinilai dari beberapa kategori antara lain:

\section{Kondisi Bangunan Dan Kepemilikan Lahan}

Tingkat kekumuhan dari sisi kondisi bangunan, meliputi 2 katagori yaitu keteraturan dan kepadatan bangunan yang dinyatakan dalam bentuk persentase. Sementara dari kepemilikan lahan pada semua Kecamatan kumuh di kabupaten Langkat bernilai negatif, karena tidak memiliki status kepemilikan lahan yang jelas. Kecamatan Tanjung Pura, nilai ketidateraturan bangunan mencapai $60 \%$ dan tingkat Kepadatan Bangunan 23-25\% unit/ha. Kecamatan Secanggang, Jumlah bangunan yang ada di Desa Selotong 71 unit dengan luas kawasan 1,8 ha. Jaring Halus 744 unit dengan luas kawasan 13,11 Ha dan Kwala Besar berjumlah 310 bangunan dengan luas kawasan sebesar 5,86 Ha. Dari sudut ketidakerturan bangunan berkisar $71-75 \%$ dan tingkat kepadatan bangunan antara 39-53\% unit/ha.

Kecamatan Brandan Barat, Jumlah bangunan yang ada di Desa Perlis sebanyak 923 unit, dengan luas kawasan sebesar 19,51 $\mathrm{Ha}$, dan Kelantan berjumlah sebanyak 295 unit rumah, dengan luas wilayah teridentifikasi kumuh sebesar 4,7 Ha. Kecamatan Gebang, Jumlah bangunan yang ada di Desa Kwala Gebang berjumlah 397 unit dengan luas kawasan sebesar 15,32 Ha, dan Pasar Rawa berjumlah sebanyak 109 unit rumah, dengan luas wilayah teridentifikasi kumuh sebesar 3,7 Ha. Untuk tingkat keteraturan bangunan di dua desa tersebut di lihat dari arah orientasi bangunan terhadap jalan yang ada dan kesamaan arah muka bangunan setiap rumahnya. Dari hasil observasi lapangan, terlihat keteraturan bangunan di dua desa masing umumnya sudah memiliki kesamaan orientasi muka bangunan, atau sekitar $40 \%$ bangunan masih kurang teratur. Kecamatan Pangkalan Susu, Jumlah bangunan yang ada di Desa Beras Basah berjumlah sebanyak 776 unit rumah, dengan luas wilayah teridentifikasi kumuh sebesar 12,6 Ha. Untuk tingkat keteraturan bangunan dari hasil observasi lapangan, terlihat keteraturan bangunan di Desa Beras Basah masing kurang memiliki kesamaan orientasi muka bangunan, yang teratur hanya rumah yang berada di sekitar jalan lingkungan yang ada atau masih kurang memiliki kesamaan orientasi. Dengan nilai presentase 60\% bangunan masih kurang teratur.

Kecamatan Pematang Jaya, Jumlah bangunan yang ada di Desa Serang Jaya Hilir berjumlah sebanyak unit 84 rumah, dengan luas wilayah teridentifikasi kumuh sebesar 4,88 Ha, dengan demikian tingkat kepadatan bangunan adalah 17 unit/ha. Nilai keteraturan bangunan di Desa Serang Jaya Hilir masih kurang memiliki kesamaan orientasi muka bangunan, yang teratur hanya rumah yang berada di sekitar jalan lingkungan yang ada, dengan nilai $70 \%$ bangunan masih kurang teratur. Kecamatan Sei Lepan, Untuk kriteria bangunan ada 3 indikator yang dijadikan permasalahan kumuh yaitu Ketidakteraturan Bangunan, Kepadatan Bangunan, dan Bangunan yang tidak sesuai dengan persyaratan teknis bangunan. Dari 3 indikator ini, adapun yang menjadi permasalahan bangunan di kelurahan Sei Bilah dan Sei Bilah Timur bahwasannya ketidak teraturan bangunan memiliki persentase yang cukup tinggi di kelurahan Sei Bilah dan Sei Bilah Timur, sedangkan untuk kepadatan bangunan yang ada dapat dikatakan masih rendah dan bangunan yang kondisi tidak sesuai dengan persyaratan teknis bangunan di 2 kelurahan persentasenya lebih dari $50 \%$.

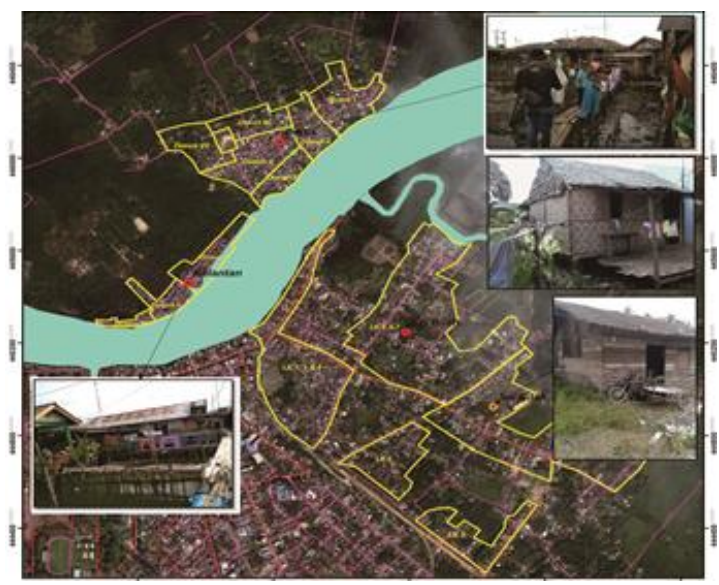

Gambar 2. Gambaran Analisis Kondisi Bangunan Sumber: Hasil Survey 


\section{Kondisi Jalan Lingkungan}

Parameter kekumuhan pada kondisi jalan dilihat dari cakupan pelayanan dan jenis konstruksi jalan yang ada. Kecamatan Tanjung Pura dua desa yaitu Desa Pematang Cengal dan Bubun, seluruh kawasan permukiman telah dilayani oleh jaringan jalan, namun kondisi perkerasan jalan yang belum memadai, umumnya masih berkonstruksi tanah/tanpa perkerasan. Dengan demikian wajah kawasan ini tampak kurang baik.

Kecamatan Secanggang, pada ke tiga desa tersebut, seluruh kawasan permukiman telah dilayani oleh jaringan jalan dengan kondisi perkerasan tanah dan beton. Perkerasan jalan beton terdapat di dua desa yaitu Jaring Halus dan Kwala Besar, sedangkan Desa Selotong umumnya tanah. Kecamatan Brandan Barat, seluruh kawasan permukiman telah dilayani oleh jaringan jalan dengan kondisi jalan tanah, papan dan beton. Kecamatan Gebang, pada ke dua desa tersebut, seluruh kawasan permukiman telah dilayani oleh jaringan jalan dengan kondisi jalan tanah dan beton.

Kecamatan Pangkalan Susu, pada Desa Beras Basah tersebut, seluruh kawasan permukiman telah dilayani oleh jaringan jalan dengan kondisi jalan tanah, papan, aspal dan beton. Kecamatan Pematang Jaya, Pada Desa Serang Jaya Hilir tersebut, seluruh kawasan permukiman telah dilayani oleh jaringan jalan dengan kondisi jalan tanah. Kecamatan Sei Lepan, cakupan pelayanan jalan lingkungan dan kualitas permukaan jalan lingkungan yang tidak sesuai persyaratan teknis.

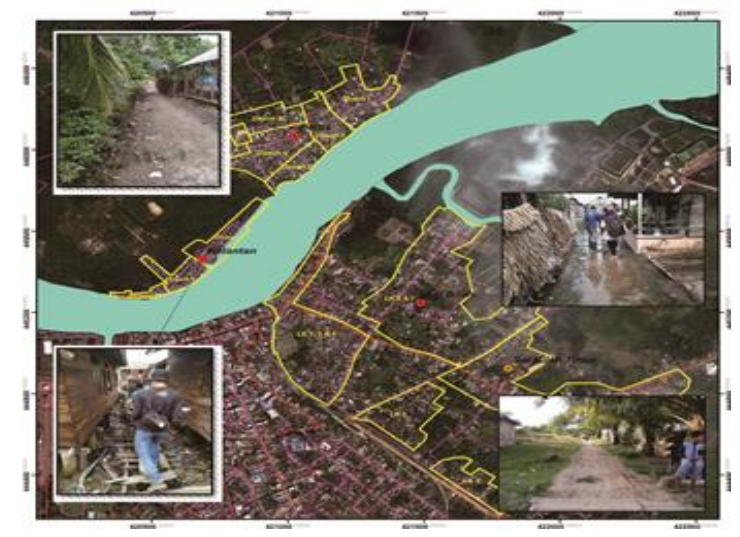

Gambar 3. Gambaran Analisis Jalan Lingkungan Sumber: Hasil Survey

\section{Kondisi Penyediaan Air Minum}

Pada tiap Desa di setiap Kecamatan kondisi air bersih dan air minum yang tersedia sudah aman, dengan indikator tidak berbau, tidat berwarna, dan tidak berasa. Selain menggunakan sumur bor, masyarakat juga memanfaatkan air yang bersumber dari PDAM dan air minum bersumber dari air kemasan isi ulang yang dikelola oleh masyarakat setempat.

Sementara pada Kecamatan Sei Lepan di kelurahan Sei Bilah dan Sei Bilah Timur permasalahan air minum yang layak untu dikonsumsi menjadi permasalahan serius untuk segera ditangani. Dikarenakan persentase terpenuhinya kebutuhan air minum yang masih sangat rendah dan permasalahan air minum terjadi dikarenakan lokasi wilayah kelurahan yang dekat pantai sehingga sedikit banyaknya menyulitkan masyarakat untuk dapat mengakses air minum yang layak.

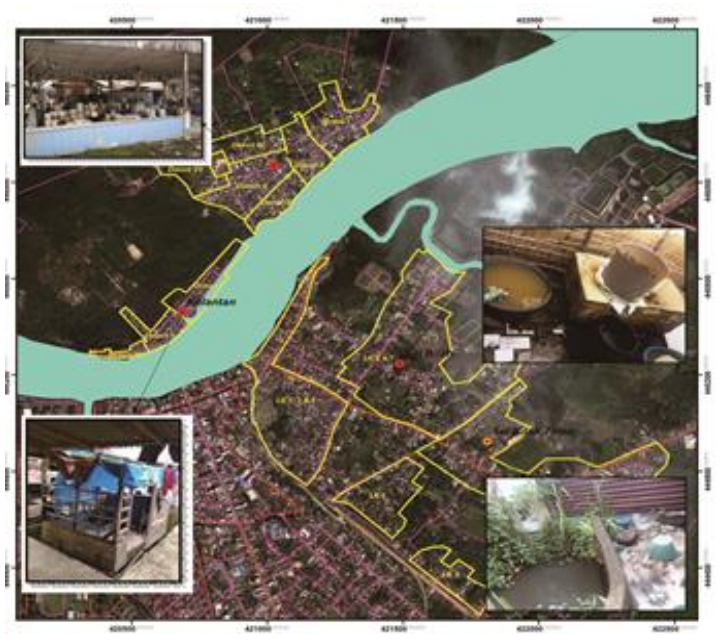

Gambar 4. Gambaran Analisis Penyediaan Air Minum

Sumber: Hasil Survey

\section{Kondisi Drainase Lingkungan}

Kondisi drainase lingkungan terdiri dari 5 bagian yaitu diantaranya ketidakmampuan drainase untuk mengalirkan limpasan air, ketidaktersediaan drainase, ketidakterhubungan drainase dengan system drainase perkotaan, tidak terpeliharanya drainase, dan kualitas konstruksi drainase. Secara umum area yang tidak mampu mengalirkan limpasan air di kecamatan ini $60 \%$, dengan kondisi drainase yang kurang terpelihara. Dibeberapa lokasi terjadi genangan 
bila hujan turun dengan kedalam genangan sekitar $30 \mathrm{~cm}$ selama 2 jam.

Kondisi drainase di tiga desa tersebut tidak tersedia, karena umumnya berada pada daerah pinggir sungai dan rawa. Kondisi drainase di dua desa tersebut sangat minim, karena umumnya berada pada daerah pinggir laut dan rawa. Ada beberapa lokasi kawasan yang sudah dibangun drainase dengan konstruksi beton, namun belum tersambung secara keseluruhan dengan system drainase setempat. Umumnya kondisi konstruksi drainase tanah dengan kedalam sangat dangkal karena sedimentasi.

Kondisi drainase di dua desa tersebut sangat minim, sehingga sering mengalami genangan kalau hujan dengan ketinggian genangan lebih dari $10 \mathrm{~cm}$. Umumnya kondisi konstruksi drainase tanah dengan dalam sangat dangkal akibat sedimentasi umumnya berada pada daerah pinggir laut dan rawa, seperti pada Desa Serang Jaya Hilir. Ada beberapa lokasi kawasan yang sudah dibangun drainase dengan konstruksi beton, dan hampir semua sudah tersambung secara keseluruhan dengan sistem drainase setempat. Dan Kelurahan Sei Bilah dan Sei Bilah Timur nilai indikator ketidak mampuan mengalirkan limpasan air yang nilainya rendah (di bawah 50\%) sedangkan 4 indikator lainnya nilainya semua di atas $50 \%$.

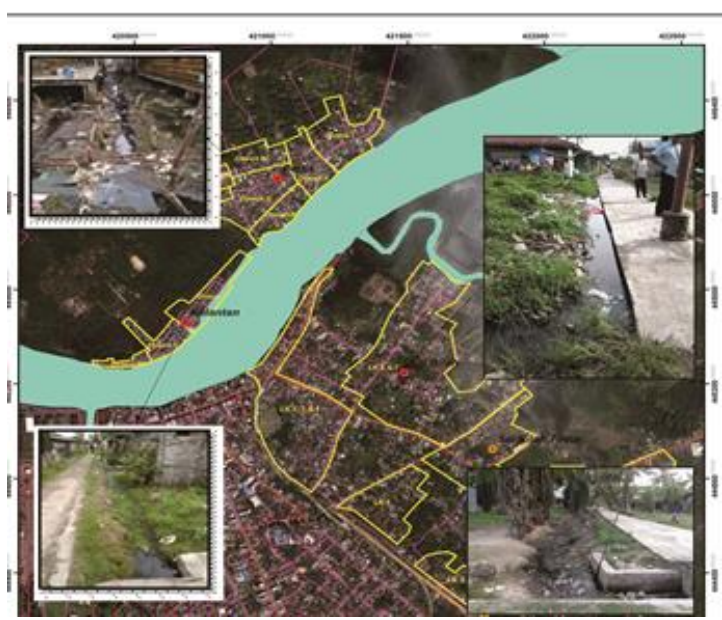

Gambar 5. Gambaran Analisis Drainase Lingkungan

Sumber: Hasil Survey

\section{Kondisi Pengelolaan Air Limbah}

Sistem pengelolaan air limbah di desa Pematang Cengal dan Desa Bubun belum memenuhi standar teknis yang dipersyaratkan oleh kementerian. Pada daerah yang tidak berada pada kawasan pinggir sungai atau rawa, sistem pengelolaan limbah menggunakan tangki septik sederhana, namun yang berada pada daerah rawa atau tepi sungai, menggunakan sistem jamban.

Sistem pengelolaan air limbah di kawasan kumuh Kecamatan Secanggang, Kecamatan Brandan Barat, Kecamatan Gebang, Kecamatan Pangkalan Susu menggunakan sistem setempat yaitu tangki septik rumah tangga dan sistem MCK komunal, serta jamban pada rumah yang berada pada daerah rawa dan pinggir sungai. Untuk Desa Jaring Halus dan Kwala Besar, Pemerintahan Kabupaten Langkat sudah menyediakan MCK namun masih terbatas dan kondisinya ada yang sudah tidak terawat lagi.

Untuk kriteria air limbah masyarakat ada 2 indikator di dalamnya untuk mengukur parameter kekumuhan suatu wilayah yaitu: sistem pengelolaan air limbah tidak sesuai persyaratan teknis dan prasarana dan sarana pengelolaan air limbah tidak sesuai dengan persyaratan teknis. Permasalahan air limbah masyarakat d kelurahan Sei Bilah dan Sei Bilah Timur menyumbangkan persentase yang cukup besar untuk kekumuhan yang terjadi di 2 kelurahan ini. Permasalahan yang terjadi pada pengelolaan air limbah masyarakat di 2 kelurahan ini berpusat pada sistem pengelolaan air limbah masyarakat dan juga terkait dengan sarana dan prasarana pengelolaan air limbah.

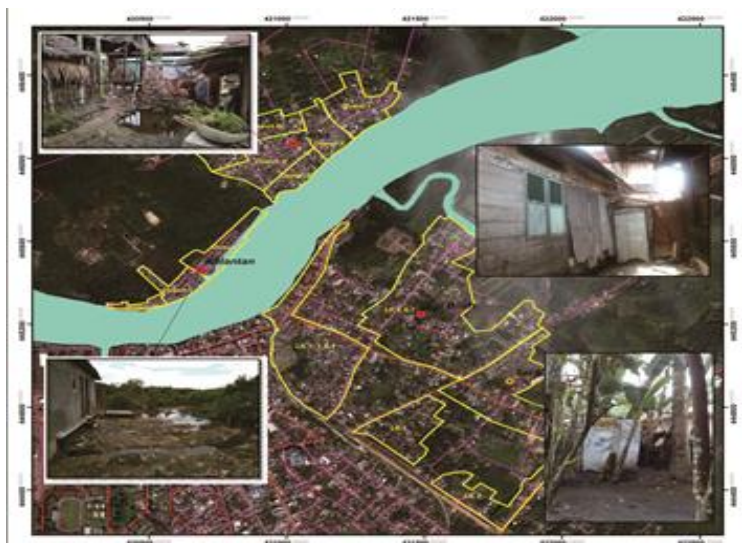

Gambar 6. Gambaran Analisis Pengelolaan Air Limbah Sumber: Hasil Survey 


\section{Kondisi Pengelolaan Persampahan}

Pengelolaan sampah di kawasan kumuh pada semua Desa di semua Kecamatan belum memiliki system pengelolaan yang baik dan terorganisir. Pengelolaan sampah hanya dilakukan oleh masyarakat setempat dengan sistim bakar, dan buang ke sungai atau rawa. Untuk itu, kondisi lingkungan sangat kurang baik, sehingga perlu penanganan yang lebih baik dan terencana dengan konsep $3 \mathrm{R}$.

Pada kriteria persampahan terdapat 3 indikator di dalamnya yaitu prasarana dan sarana persampahan tidak sesuai dengan persyaratan teknis, sistem pengelolaan persampahan yang tidak sesuai standard teknis, dan tidak terpeliharanya sarana dan prasarana pengelolaan persampahan. Pada kelurahan Sei Bilah dan Sei Bilah Timur, permasalahan sampah yang berhasil didata bahwasannya penyebab kekumuhan masih minimnya sarana dan prasarana persampahan yang bisa diakses oleh masyarakat di 2 kelurahan tersebut sehingga hal iniah yang membuat permasalahan sampah menjadi persoalan utama kekumuhan di kelurahan Sei Bilah dan Sei Bilah Timur.

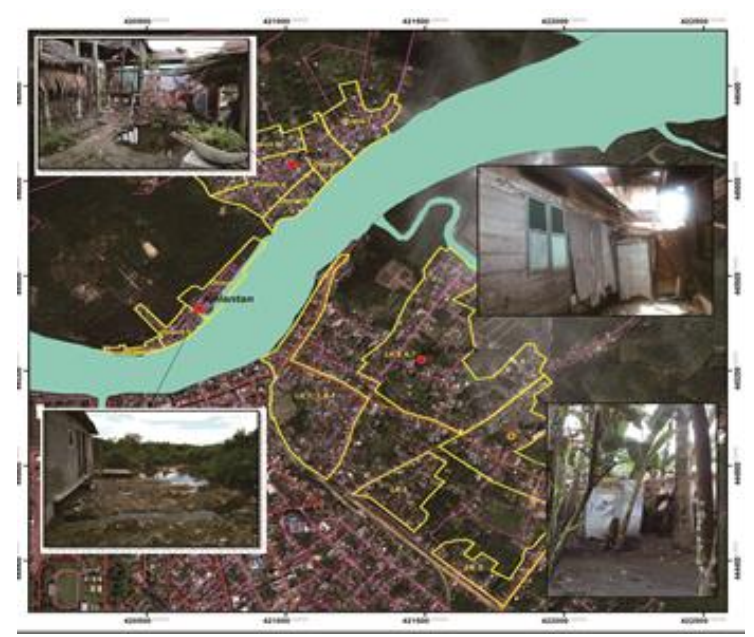

Gambar 7. Gambaran Analisis Persampahan Sumber: Hasil Survey

\section{Kondisi Proteksi Kebakaran}

Kriteria proteksi kebakaran terdiri dari 2 indikator yaitu ketidak tersediaan prasarana proteksi kebakaran dan ketidak tersediaan sarana proteksi kebakaran. Kondisi proteksi kebakaran di kawasan kumuh di seluruh Desa semua Kecamatan Kabupaten Langkat baik dari prasarana maupun sarana proteksi kebakaran ini tidak tersedia. Hal ini sangat membahayakan jika terjadi kebakaran, karena tidak ada sarana yang dapat diandalkan untuk pemadaman api, hanya mengandalkan alat sederhana yang ada berupa ember-ember dari rumah tangga yang ada, dan sumber airnya berasal dari sumur dan sungai. Untuk itu perlu pengadaan sarana dan prasarana proteksi kebakaran minimal APAR (alat pemadam api ringan) berupa racun api.

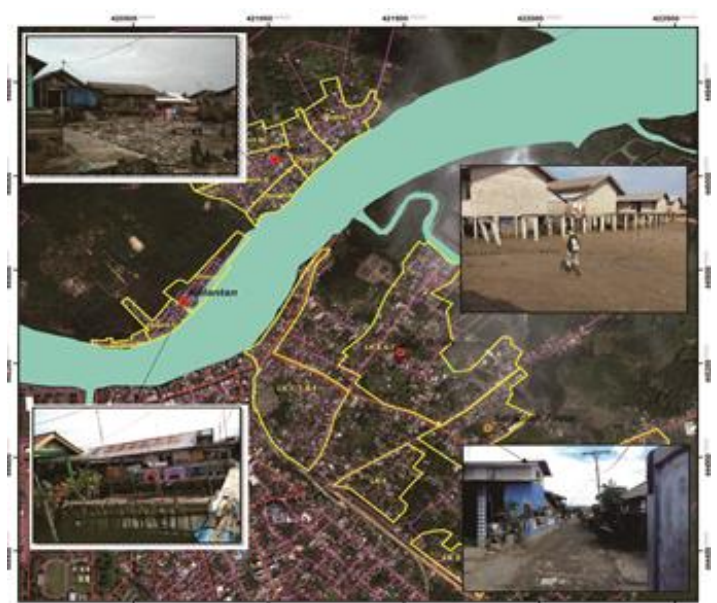

Gambar 8. Gambaran Analisis Proteksi Kebakaran Sumber: Hasil Survey

Hasil survey yang dilakukan dalam 6 Kecamatan terhadap identifikasi kawasan kumuh, maka dapat digambarkan Kawasan kumuh berada pada peta di bawah ini:

1. Kecamatan Tanjung Pura

Berdasarkan data Profil Kumuh lokasi kawasan kumuh tersebar di 2 Desa yaitu di Desa Pematang Cengal dan Bubun. Untuk jumlah lokasi kumuh yang ada di Kecamatan Tanjung Pura terdapat 3 titik lokasi kumuh. Sementara berdasarkan data rekapitulasi pendataan rumah layak huni di Desa Pematang Cengal terdapat 1.996 unit rumah yang layak huni dan 99 unit rumah tidak layak huni, kemudian untuk Desa Bubun terdapat 806 rumah layak huni dan tidak terdapat di desa tersebut rumah yang tidak layak huni. 

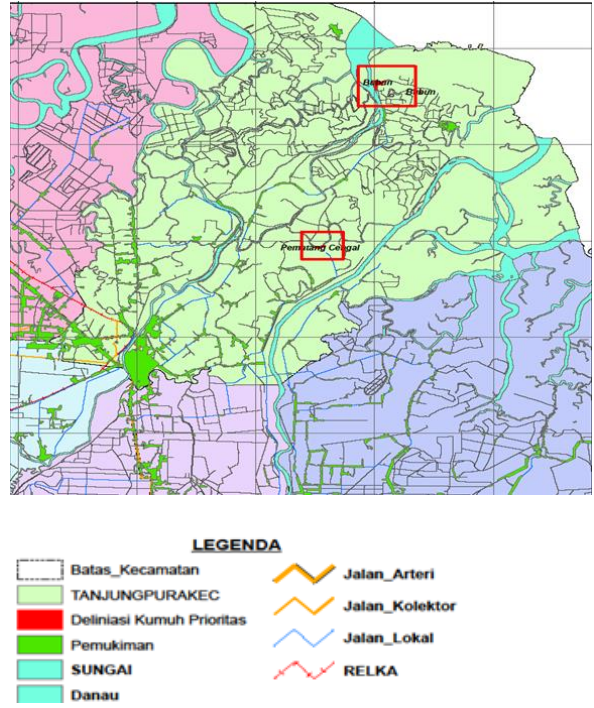

Gambar 9. Peta Sebaran Lokasi Kumuh Kec. Tanjung Pura Sumber: Hasil Analisis

2. Kecamatan Secanggang Memiliki luas 231.19 Ha dengan jumlah penduduk sebesar 68.390 jiwa dan kepadatan penduduknya $295.82 \mathrm{jiwa} / \mathrm{Ha}$.
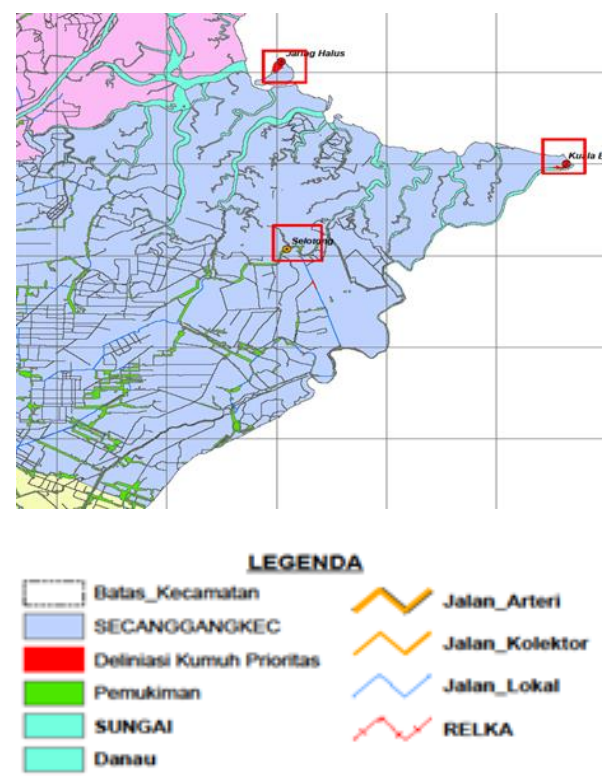

Gambar 10. Peta Sebaran Lokasi Kumuh Kecamatan Secanggang Sumber: Hasil Analisis

3. Kecamatan Brandan Barat

Luas area 89.80 Ha dengan jumlah penduduk sebesar 22.949 jiwa dan kepadatan penduduknya $255.56 \mathrm{jiwa} / \mathrm{Ha}$.

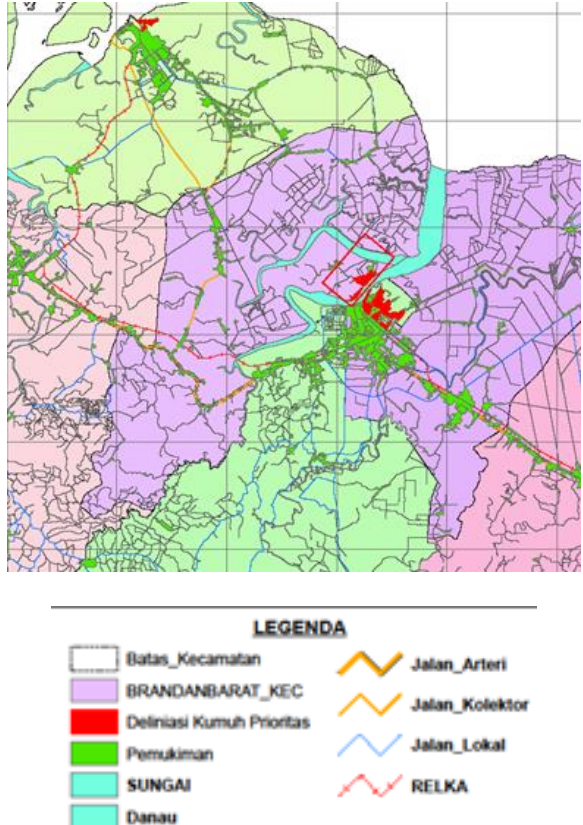

Gambar 11. Peta Sebaran Lokasi Kumuh Kecamatan Brandan Barat Sumber: Hasil Analisis

4. Kecamatan Gebang

Luas 178.49 Ha dengan jumlah penduduk sebesar 44.526 jiwa dan kepadatan penduduknya 249.46 jiwa/ Ha.
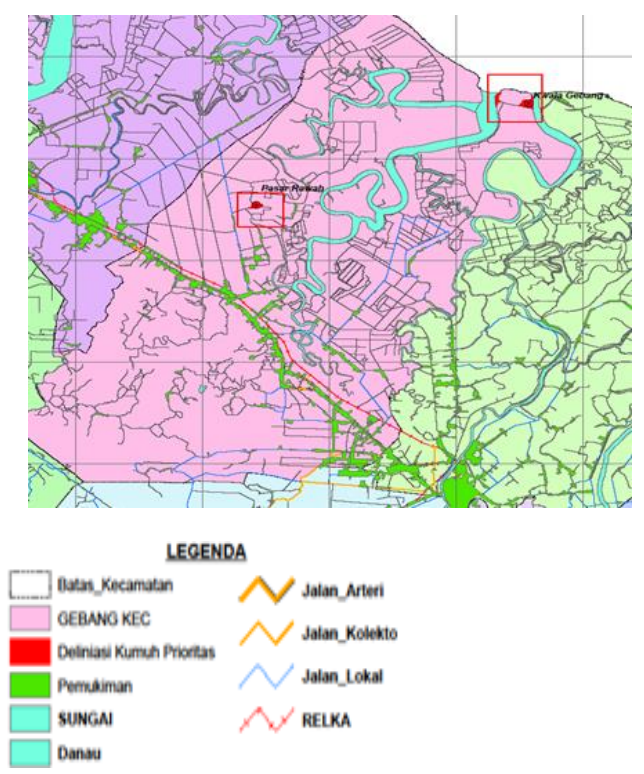

Gambar 12. Peta Sebaran Lokasi Kumuh Kecamatan Gebang Sumber: Hasil Analisis

5. Kecamatan Pangkalan Susu Memiliki luas 151.35 Ha dengan jumlah penduduk sebesar 43.486 jiwa dan kepadatan penduduknya $287.32 \mathrm{jiwa} / \mathrm{Ha}$. 


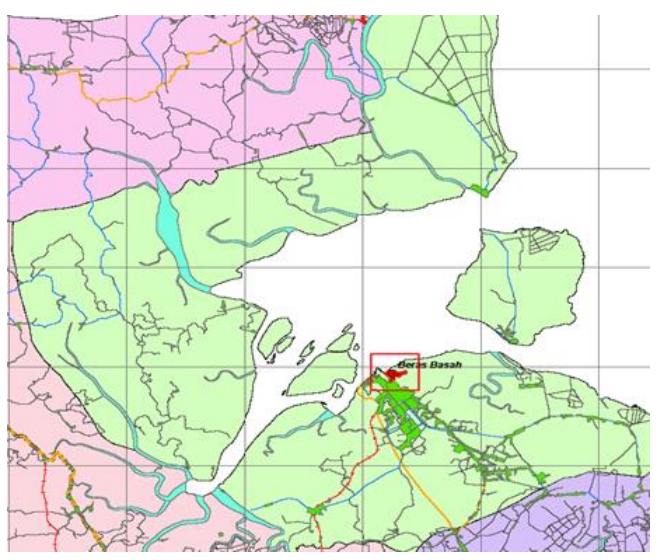

LEGENDA

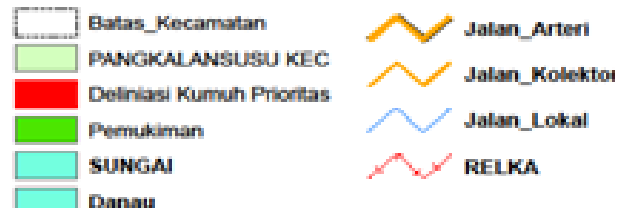

Gambar 13. Peta Sebaran Lokasi Kumuh Kecamatan Pangkalan Susu Sumber: Hasil Analisis

6. Kecamatan sei Lepan

Ada 2 kelurahan yang menjadi lokasi kumuh di kecamatan Sei Lepan yaitu: kelurahan Sei Bilah dan Sei Bilah Timur.

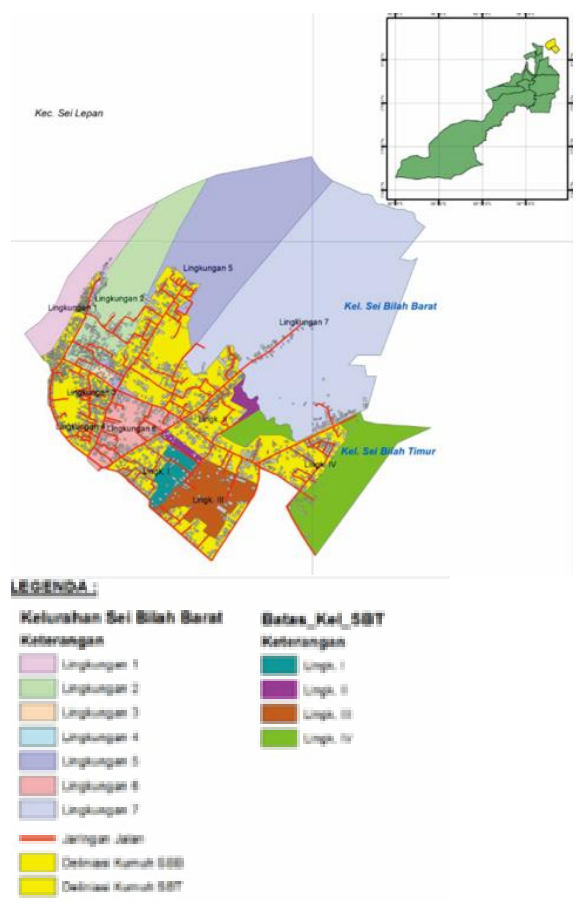

Gambar 14. Peta Sebaran Lokasi Kumuh Kecamatan Sei Lepan Sumber: Hasil Analisis
Hasil penilaian dengan metode AHP dengan melakukan perbandingan dan penilaian terhadap indicator permukiman kumuh dapat dilihat pada tabel 2 pada lampiran. Hasil identifikasi menunjukkan kawasan penanganan kumuh prioritas terbagi dalam 3 kawasan yaitu:

- Kawasan Prioritas 1 (P1): Kelurahan Sei Bilah, Kelurahan Sei Bilah Timur, Desa Perlis, Desa Kelantan

- Kawasan Prioritas 2 (P2): Desa Pematang Cengal dan Bubun.

- Kawasan Prioritas 3 (P3): Desa Selotong, Desa Jaring Halus, dan Desa Kwala Besar

- Kawasan Prioritas 4 (P4) : Desa Beras Basah

- Kawasan Prioritas 5 (P5) : Desa Serang Jay Hilir

- Kawasan Prioritas 6 (P6) : Desa Kwala Gebang dan Desa Pasar Rawa

\section{KESIMPULAN}

Dari hasil identifikasi, pengolahan data yang dilakukan terhadap 6 Kecamatan yang menjadi prioritas bahwasannya terdapat 13 kawasan yang menjadi prioritas Kawasan kumuh dilihat dari 7 indikator kumuh yaitu Kondisi bangunan, kondisi jalan lingkungan, kondisi penyediaan air minum, kondisi drainase, kondisi pengelolaan air limbah, persampahan, dan proteksi kebakaran. Indikator ini juga melihat pertimbangan lain dengan melihat legalitas lahan kepemilikan. Penilaian dari 7 indikator tersebut akan dikategorikan dalam tingkat kekumuhan berat, kumuh sedang dan kumuh ringan. Masingmasing nilai diantara 56-68 dengan kategori kumuh sedang. Nilai kekumuhan tertinggi ada pada Kawasan Sei Bilah dengan nilai 70, sei bilah utara 68 , selotong, serang jaya hilir 67 , perlis, klantan dengan nilai 65 , kwala besar nilai 64, Kwala gebang nilai 63, bubun dengan nilai 62 , pasar rawa nilai 61 , pematang cenggal nilai 59 , jarring halus nilai 56 , dan beras basah nilai 48.

Nilai tersebut akan diperbandingkan dengan aspek pertimbangan lainnya yaitu 
legalitas lahan penduduk. Sehingga didapat tingkat perioritas 1 yaitu Sei Bilah, Sei Bilah Timur, Prioritas 2 Pematang cenggal, Bubun, Prioritas 3 yaitu Selotong, Jaring Halus, Kwala Besar, Prioiras 4 Beras Basah, Prioritas 5 Serang Jaya Hilir, Perlis, Kelantan, dan Serang Jaya Hilir dan Prioritas 6 yaitu Kwala Gebang dan Pasar Rawa.

Hasil penilaian tehadap kawasan kumuh ini, disarankan dapat membantu dalam penelitian lanjutan terhadap penanganan Kawasan kumuh terhadap lingkungannya.

\section{REFERENSI}

Ahaliki, B. (2020). Pemetaan Kawasan Permukiman Kumuh Perkotaan Menggunakan Metode Simple Additive Weighting. $2(2)$. https://doi.org/10.37905/jji.v2i9.7308

Crysta, E. A., \& Budisusanto, Y. (2018). ANALISIS TINGKAT KEKUMUHAN DAN POLA PENANGANANNYA PADA LOKASI PERMUKIMAN (Studi Kasus: Kelurahan Keputih, Surabaya). Geoid, 13(2), 109. https://doi.org/10.12962/j24423998.v13i2.36 81

Ilmy, H. F., \& Budisusanto, Y. (2017). Identifikasi Penentuan Prioritas Kriteria Kawasan Permukiman Kumuh Perkotaan menggunakan Metode AHP (Analytical Hierarcy Process). Jurnal Teknik ITS, 6(1), 19-21. https://doi.org/10.12962/j23373539.v6i1.215 10

Istikasari, M., \& Khadiyanto, P. (2014). Identifikasi Permukiman Kumuh Di Pusat Kota Jambi Identification of Slums Area in the Center of Jambi City. Jurnal Ruang, 2(4), 301-310.
Kasus, S., Pancuran, K., \& Oleh, T. D. (2006). Eny Endang Surtiani MAGISTER TEKNIK PEMBANGUNAN WILAYAH DAN KOTA PROGRAM PASCA SARJANAUNIVERSITAS DIPONEGORO SEMARANG.

Komunikasi, M., Lingkungan, T., Kumuh, P., Mutaqin, Z., Persada, C., \& Suroso, E. (2019). Jurnal Presipitasi Prioritas Penentuan Peningkatan Kualitas Lingkungan. 16(2), 2232.

Marx, B., Stoker, T., \& Suri, T. (2013). The economics of slums in the developing world. Journal of Economic Perspectives, 27(4), 187-210. https://doi.org/10.1257/jep.27.4.187

PUPR. (2016). No 2/PRT/M/2016 tentang Peningkatan Kualitas Terhadap Perumahan Kumuh dan Permukiman Kumuh.

Sastanti, S. Y., \& Fibriani, C. (2019). Analisis Tingkat Permukiman Kumuh Menggunakan Metode AHP Berbasis SIG pada Kota Magelang. Jurnal Nasional Teknologi Dan Sistem Informasi, 5(1), 69-78. https://doi.org/10.25077/teknosi.v5i1.2019.69 $-78$

Stabat, P. K. (n.d.). RPPJMD Kabupaten Langkat 2014-2019.

Wijaya, D. W. (2016). Perencanaan Penanganan Kawasan Permukiman Kumuh (Studi Penentuan Kawasan Prioritas untuk Peningkatan Kualitas Infrastruktur pada Kawasan Pemukiman Kumuh di Kota Malang). Jurnal Ilmiah Administrasi Publik, 2(1), 1-10. https://doi.org/10.21776/ub.jiap.2016.002.01. 1

Zulkarnaini, W. R., Elfindri, E., \& Sari, D. T. (2019). Faktor-Faktor Yang Mempengaruhi Permukiman Kumuh di Kota Bukittinggi. $\begin{array}{lll}\text { Jurnal Planologi, } 16(2), & 169 .\end{array}$ https://doi.org/10.30659/jpsa.v16i2.5047

Tabel 2. Hasil Penilaian Berdasarkan Identifikasi Kawasan Kumuh

\begin{tabular}{|c|c|c|c|c|c|c|c|c|c|c|c|c|c|c|c|c|c|}
\hline \multirow[b]{2}{*}{ No } & \multirow[b]{2}{*}{ Aspek } & \multirow[b]{2}{*}{ Kriteria } & \multirow[b]{2}{*}{$\begin{array}{c}\text { Persentase } \\
\text { Indikator \& } \\
\text { Parameter }\end{array}$} & \multirow[b]{2}{*}{ Nilai } & \multicolumn{13}{|c|}{ Lokasi Permukiman Kumuh } \\
\hline & & & & & 㺼 & 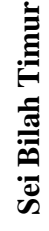 & 里 & 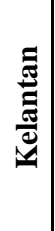 & 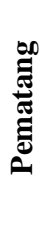 & 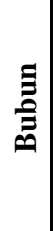 & 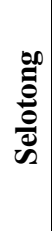 & 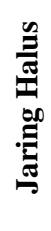 & 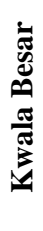 & 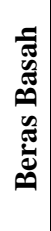 & 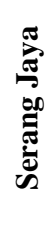 & 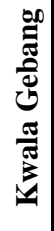 & 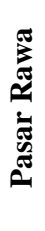 \\
\hline \multirow{5}{*}{1} & \multirow{5}{*}{$\begin{array}{l}\text { Kondisi } \\
\text { Bangunan }\end{array}$} & \multirow{3}{*}{$\begin{array}{l}\text { Tingkat } \\
\text { memiliki } \\
\text { Keteraturan } \\
\text { Bangunan }\end{array}$} & $76 \%-100 \%$ & 5 & 5 & 5 & & & 5 & & & & & & & & \\
\hline & & & $51 \%-75 \%$ & 3 & & & 3 & 3 & & 3 & 3 & 3 & 3 & 3 & 3 & & \\
\hline & & & $25 \%-50 \%$ & 1 & & & & & & & & & & & & 1 & 1 \\
\hline & & \multirow{2}{*}{$\begin{array}{l}\text { Tingkat } \\
\text { Kepadatan }\end{array}$} & $75 \%-100 \%$ & 5 & & & & & & & & & & & & & \\
\hline & & & $51 \%-75 \%$ & 3 & & & & & & & & & & & & & \\
\hline
\end{tabular}




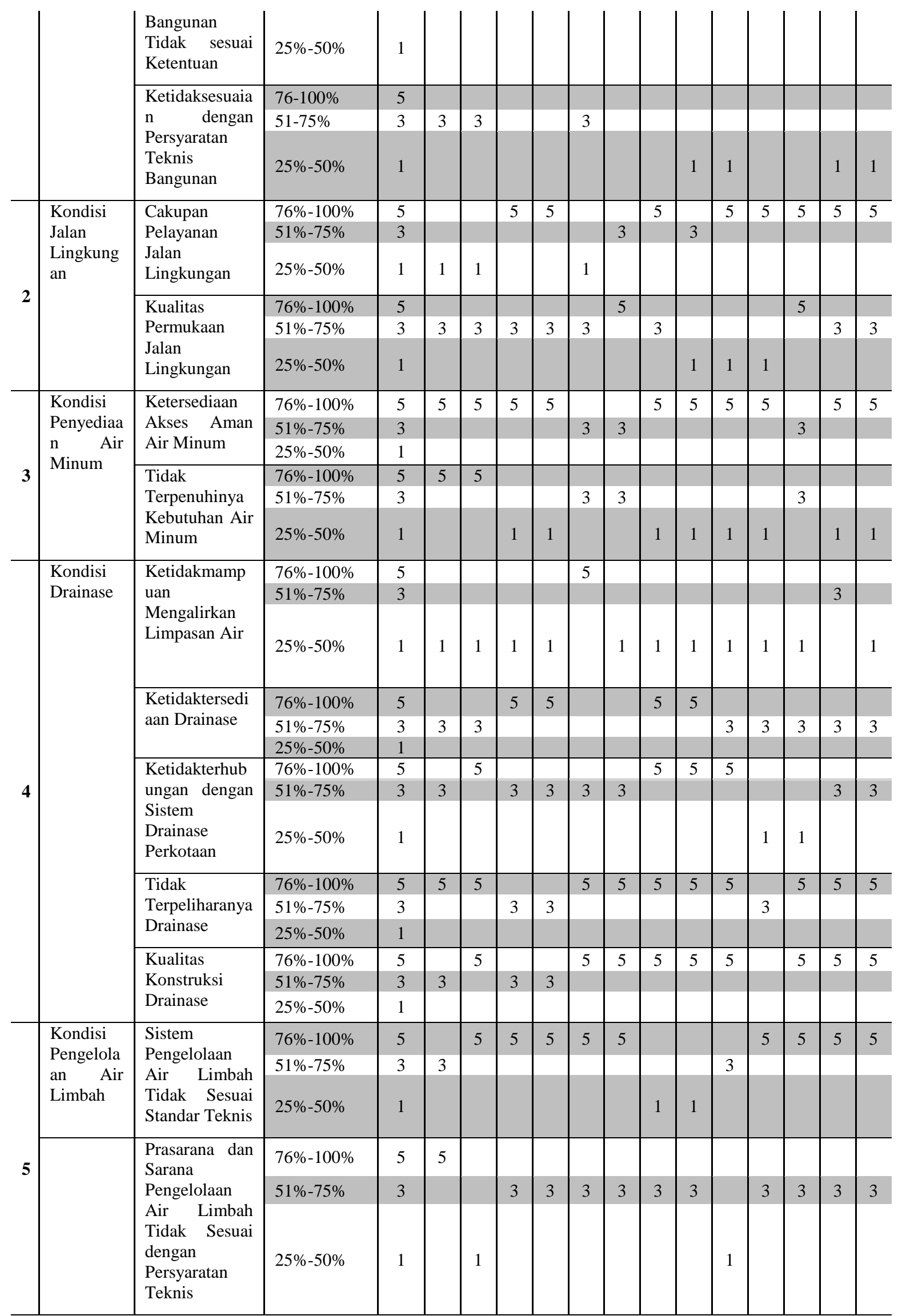




\begin{tabular}{|c|c|c|c|c|c|c|c|c|c|c|c|c|c|c|c|c|c|}
\hline & \multirow{9}{*}{$\begin{array}{l}\text { Kondisi } \\
\text { Pengelola } \\
\text { an } \\
\text { Persampa } \\
\text { han }(\mathrm{F})\end{array}$} & \multirow{3}{*}{$\begin{array}{l}\text { Prasarana dan } \\
\text { Sarana } \\
\text { Persampahan } \\
\text { pada lokasi } \\
\text { perumahan dan } \\
\text { permukiman } \\
\text { Tidak Sesuai } \\
\text { dengan } \\
\text { Persyaratan } \\
\text { Teknis }\end{array}$} & $76 \%-100 \%$ & 5 & 5 & 5 & 5 & 5 & & 5 & 5 & & 5 & & 5 & 5 & 5 \\
\hline & & & $51 \%-75 \%$ & 3 & & & & & & & & & & & & & \\
\hline & & & $25 \%-50 \%$ & 1 & & & & & 1 & & & 1 & & 1 & & & \\
\hline \multirow{6}{*}{6} & & \multirow{3}{*}{$\begin{array}{l}\text { Sistem } \\
\text { Pengelolaan } \\
\text { Persampahan } \\
\text { Tidak Sesuai } \\
\text { Standar Teknis }\end{array}$} & $76 \%-100 \%$ & 5 & 5 & & 5 & 5 & 5 & 5 & 5 & 5 & 5 & 5 & 5 & 5 & 5 \\
\hline & & & $51 \%-75 \%$ & 3 & & & & & & & & & & & & & \\
\hline & & & $25 \%-50 \%$ & 1 & & 1 & & & & & & & & & & & \\
\hline & & \multirow{3}{*}{$\begin{array}{l}\text { Tidak } \\
\text { Terpeliharanya } \\
\text { Sarana dan } \\
\text { Prasarana } \\
\text { Pengelolaan } \\
\text { Persampahan }\end{array}$} & $76 \%-100 \%$ & 5 & 5 & 5 & 5 & 5 & & 5 & 5 & & 5 & & 5 & & \\
\hline & & & $51 \%-75 \%$ & 3 & & & & & 3 & & & & & & & & \\
\hline & & & $25 \%-50 \%$ & 1 & & & & & & & & 1 & & 1 & & & \\
\hline \multirow[t]{5}{*}{7} & \multirow{5}{*}{$\begin{array}{l}\text { Kondisi } \\
\text { Proteksi } \\
\text { Kebakara } \\
\text { n }(\mathrm{G})\end{array}$} & \multirow{3}{*}{$\begin{array}{l}\text { Ketidaktersedi } \\
\text { aan Prasarana } \\
\text { Proteksi } \\
\text { Kebakaran }\end{array}$} & $76 \%-100 \%$ & 5 & 5 & 5 & 5 & 5 & & 5 & 5 & 5 & 5 & 5 & 5 & 5 & 5 \\
\hline & & & $51 \%-75 \%$ & 3 & & & & & 3 & & & & & & & & \\
\hline & & & $25 \%-50 \%$ & 1 & & & & & & & & & & & & & \\
\hline & & $\begin{array}{l}\text { Ketidaktersedi } \\
\text { aan Sarana } \\
\text { Proteksi } \\
\text { Kebakaran }\end{array}$ & $\begin{array}{l}76 \%-100 \% \\
51 \%-75 \% \\
25 \%-50 \%\end{array}$ & $\begin{array}{l}5 \\
3\end{array}$ & 5 & 5 & 5 & 5 & 3 & 5 & 5 & 5 & 5 & 5 & 5 & 5 & 5 \\
\hline & & \multicolumn{3}{|l|}{ SUBTOTAL } & $\begin{array}{l}7 \\
0\end{array}$ & $\begin{array}{l}6 \\
8\end{array}$ & $\begin{array}{l}6 \\
5\end{array}$ & $\begin{array}{l}6 \\
5\end{array}$ & $\begin{array}{l}5 \\
9\end{array}$ & $\begin{array}{l}6 \\
2\end{array}$ & $\begin{array}{l}6 \\
7\end{array}$ & $\begin{array}{l}5 \\
6\end{array}$ & $\begin{array}{l}6 \\
4\end{array}$ & $\begin{array}{l}4 \\
8\end{array}$ & $\begin{array}{l}6 \\
7\end{array}$ & $\begin{array}{l}6 \\
3\end{array}$ & $\begin{array}{l}6 \\
1\end{array}$ \\
\hline
\end{tabular}

Tabel 3. Hasil Penilaian Penentuan Klasifikasi dan Skala Prioritas Penanganan

\begin{tabular}{|c|c|c|c|c|c|c|c|c|c|c|c|c|c|}
\hline \multirow{3}{*}{$\begin{array}{l}\mathbf{N} \\
\mathbf{o}\end{array}$} & \multirow{3}{*}{ Kawasan } & \multirow{3}{*}{$\begin{array}{c}\text { Jumlah } \\
\text { nilai } \\
\text { penilaian } \\
\text { kriteria } \\
\text { dan } \\
\text { indikator } \\
\text { kekumuh } \\
\text { an }\end{array}$} & \multicolumn{3}{|c|}{$\begin{array}{c}\text { Tingkat } \\
\text { kekumuhan }\end{array}$} & \multirow{3}{*}{$\begin{array}{c}\text { Jumlah } \\
\text { nilai } \\
\text { aspek } \\
\text { pertim } \\
\text { bangan } \\
\text { lain }\end{array}$} & \multicolumn{3}{|c|}{$\begin{array}{c}\text { Pertimbangan } \\
\text { lain }\end{array}$} & \multicolumn{2}{|c|}{$\begin{array}{c}\text { Legalitas } \\
\text { lahan }\end{array}$} & \multirow{3}{*}{ Klasifikasi } & \multirow{3}{*}{$\begin{array}{c}\text { Skala } \\
\text { prioritas }\end{array}$} \\
\hline & & & 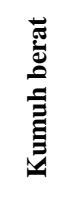 & 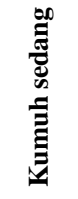 & 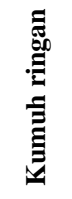 & & 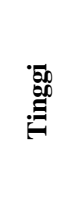 & 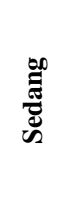 & 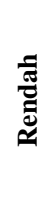 & 司 & 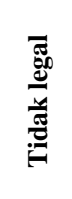 & & \\
\hline & & & $\begin{array}{l}(71- \\
95) \\
\end{array}$ & $\begin{array}{l}(45- \\
70)\end{array}$ & $\begin{array}{l}(19- \\
44)\end{array}$ & & $\begin{array}{l}(11- \\
15)\end{array}$ & $\begin{array}{l}\text { (6- } \\
\text { 10) }\end{array}$ & $\begin{array}{l}(1- \\
5)\end{array}$ & $\begin{array}{c}\text { Nilai } \\
(+)\end{array}$ & $\begin{array}{l}\text { Nila } \\
\text { i (-) }\end{array}$ & & \\
\hline 1 & Sei Bilah & 70 & & $\mathrm{X}$ & & 11 & $X$ & & & & $\mathrm{X}$ & B2 & Prioritas 1 \\
\hline 2 & $\begin{array}{l}\text { Sei Bilah } \\
\text { Timur }\end{array}$ & 68 & & $\mathrm{X}$ & & 11 & $\mathrm{X}$ & & & & $\mathrm{X}$ & B2 & Prioritas 5 \\
\hline 3 & Perlis & 65 & & $\mathrm{X}$ & & 9 & & $\mathrm{X}$ & & & $\mathrm{X}$ & B4 & Prioritas 5 \\
\hline 4 & Kelantan & 65 & & $\mathrm{X}$ & & 7 & & $\mathrm{X}$ & & & $\mathrm{X}$ & B4 & Prioritas 2 \\
\hline 5 & $\begin{array}{l}\text { Pematang } \\
\text { Cengal }\end{array}$ & 59 & & $\mathrm{X}$ & & 7 & & $\mathrm{X}$ & & & $\mathrm{X}$ & B4 & Prioritas 2 \\
\hline 6 & Bubun & 62 & & $X$ & & 7 & & $X$ & & & $\mathrm{X}$ & B4 & Prioritas 3 \\
\hline 7 & Selotong & 67 & & $\mathrm{X}$ & & 9 & & $\mathrm{X}$ & & & $\mathrm{X}$ & B4 & Prioritas 3 \\
\hline 8 & $\begin{array}{l}\text { Jaring } \\
\text { Halus }\end{array}$ & 56 & & $\mathrm{X}$ & & 11 & $X$ & & & & $X$ & B2 & Prioritas 3 \\
\hline 9 & $\begin{array}{l}\text { Kwala } \\
\text { Besar }\end{array}$ & 64 & & $\mathrm{X}$ & & 11 & $X$ & & & & $\mathrm{X}$ & B2 & Prioritas 4 \\
\hline 10 & $\begin{array}{l}\text { Beras } \\
\text { Basah } \\
\end{array}$ & 48 & & $\mathrm{X}$ & & 11 & $X$ & & & & $\mathrm{X}$ & B2 & Prioritas 5 \\
\hline
\end{tabular}


Arsitektura : Jurnal Ilmiah Arsitektur dan Lingkungan Binaan, Vol. 19 (2) October 2021: 275-288

\begin{tabular}{lllllllll}
$\mathbf{1 1}$ & $\begin{array}{l}\text { Serang } \\
\text { Jaya Hilir }\end{array}$ & 67 & $\mathrm{X}$ & 7 & $\mathrm{X}$ & $\mathrm{X}$ & $\mathrm{B} 4$ & Prioritas 6 \\
\hline $\mathbf{1 2}$ & $\begin{array}{l}\text { Kwala } \\
\text { Gebang }\end{array}$ & 63 & $\mathrm{X}$ & 7 & $\mathrm{X}$ & $\mathrm{X}$ & $\mathrm{B} 4$ & Prioritas 6 \\
\hline $\mathbf{1 3}$ & $\begin{array}{l}\text { Pasar } \\
\text { Rawa }\end{array}$ & 61 & $\mathrm{X}$ & 7 & $\mathrm{X}$ & $\mathrm{X}$ & $\mathrm{B} 4$ & Prioritas 1 \\
\hline
\end{tabular}

